\title{
G-Protein-Associated Signal Transduction Processes Are Restored after Postweaning Environmental Enrichment in Ts65Dn, a Down Syndrome Mouse Model
}

\author{
C. Baamonde ${ }^{b} \quad$ C. Martínez-Cué ${ }^{b} \quad J$. Flórez $^{\text {b, c }} \quad$ M. Dierssen ${ }^{a}$
}

${ }^{a}$ Genes and Disease Program, Center for Genomic Regulation (CRG), Barcelona Biomedical Research Park (PRBB),

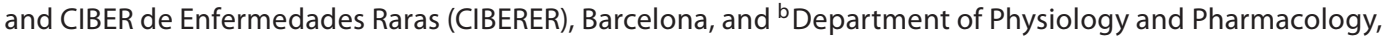
Faculty of Medicine, University of Cantabria, and ${ }^{\mathrm{C}}$ Fundación Síndrome de Down de Cantabria, Fundación Iberoamericana Down21, Santander, Spain

\section{Key Words \\ Cyclic adenosine monophosphate $\cdot$ Phospholipase $C \cdot$ Adenylyl cyclase $\cdot$ Phosphatidylinositol 4,5-bisphosphate $\cdot$ Postnatal development • Environmental enrichment • G protein transduction • Trisomic mouse model $\cdot$ Ts65Dn • Down syndrome}

\begin{abstract}
Individuals with Down syndrome (DS) present cognitive deficits that can be improved by early implementation of special care programs. However, they showed limited and temporary cognitive effects. We previously demonstrated that postnatal environmental enrichment (EE) improved clearly, though temporarily, the execution of visuospatial memory tasks in Ts65Dn mice, a DS model bearing a partial trisomy of murine chromosome 16; but in contrast to wild-type littermates, there was a lack of structural plasticity in pyramidal cell structure in the trisomic cerebral cortex. In the present study, we have investigated the impact of EE on the function of adenylyl cyclase and phospholipase $C$ as a possible mechanism underlying the time-limited improvements observed. Basal production of cyclic adenosine monophosphate (CAMP) was not affected, but responses to GTP $\gamma$ S, iso-
\end{abstract}

prenaline, noradrenaline, SKF 38393 and forskolin were depressed in the Ts65Dn hippocampus. In EE conditions, CAMP accumulation was not significantly modified in control animals with respect to nonenriched controls. However, EE had a marked effect in Ts65Dn mice, in which cAMP production was significantly increased. Similarly, EE increased phospholipase $C$ activity in Ts65Dn mice, in response to carbachol and calcium. We conclude that $\mathrm{EE}$ restores the G-protein-associated signal transduction systems that are altered in Ts65Dn mice.

Copyright $\odot 2011$ S. Karger AG, Base

Individuals with Down syndrome (DS) present cognitive deficits that can be improved by early implementation of special care programs. Positive short-term effects of those early interventions are well recognized, whereas long-term effects are less documented [1-5]. We have previously replicated this approach in an animal model of DS, the Ts $\left(17^{16}\right) 65 \mathrm{Dn}$ (Ts65Dn) [6-9]. Currently, Ts65Dn is the most accepted animal model for human trisomy 21 and includes most of the MMU16 region homologous to HSA21 (from Mrpl39 to Zfp295 in the distal telomere) [10]. Trisomic mice show cognitive deficits in spatial

\section{KARGER}

Fax +4161306 1234

E-Mail karger@karger.ch

www.karger.com (c) 2011 S. Karger AG, Basel

0378-5866/11/0335-0442\$38.00/0

Accessible online at:

www.karger.com/dne
Mara Dierssen

Genes and Disease Program, Center for Genomic Regulation (CRG) Barcelona Biomedical Research Park (PRBB) Building, Room 522.04 C/ Dr. Aiguader 88, ES-08003 Barcelona (Spain)

Tel. +34933160 140, E-Mail mara.dierssen@crg.es 
learning and memory, hyperactivity, reduced attention levels and an altered response to novel environments [1118]. Similar to what has been described in DS, we found in previous studies that postweaning environmental enrichment (EE) modified behavioral performance and learning abilities of Ts65Dn mice, temporarily improving working and reference memories [8]. However, EE was not able to induce long-term structural plasticity in trisomic mice [7] and it produced gender-specific effects so that it improved spatial learning in female but deteriorated it in male Ts65Dn mice [8].

Numerous studies have revealed disrupted post-receptor signal transduction, in particular those mediated by G-protein-regulated adenylyl cyclase (AC) [19-22] and phospholipase C (PLC) [21-24] in DS brains. Consistent changes found in myoinositol and phospholipid composition of fetal and adult DS brain membranes [25-27] may predict deregulation of PLC-linked transduction processes, and our previous studies determined a reduced ability of several brain areas to respond to the indirect (receptor-mediated) and direct stimulation of the PLC $[28]$ and AC $[29,30]$ signaling systems in Ts65Dn mice. In fact, neurotransmitters using these second messenger systems, such as the serotonergic, noradrenergic, GABAergic, and cholinergic systems, are altered in trisomic mice and DS fetuses [30-37], that may compromise shortterm memory and hippocampal function [38]. For example, the serotonin 5-HT1A [39] and 5-HT levels [40] are reduced in DS, and inhibition of 5-HT reuptake with fluoxetine restores cognitive impairments and hippocampal neurogenesis in Ts65Dn mice [41].

Our previous work suggested that the long-lasting adaptation of the AC transduction system was a key element in the effects of neonatal handling in rats [42-44], and clear alterations of AC and PLC signaling systems in DS brains. We here aimed to assess the possible changes in $\mathrm{G}$ protein signaling systems upon postweaning EE in Ts65Dn mice. As a target region, we selected the hippocampus, deeply involved in several memory tasks, including spatial memory, and deteriorated in Ts65Dn mice $[14,15,18,44]$ with structural and functional alterations [45-53] similar to those observed in DS patients $[54,55]$.

Thus, the present experiments were designed to elucidate the functioning of the AC and PLC signaling pathways in brain hippocampal membranes of naïve and enriched female Ts65Dn mice, since our previous work showed a deleterious effect of EE on male TS mice cognition related to chronic stress and enhanced aggression under EE conditions $[6,8]$.

EE Restores G-Protein-Associated Processes in a DS Model

\section{Materials and Methods}

\section{Animals}

Mice were generated by repeated backcross of Ts65Dn females to $\mathrm{C} 57 \mathrm{BL} / 6 \mathrm{Jei} \times \mathrm{C} 3 \mathrm{H} / \mathrm{HeSnJ}(\mathrm{B} 6 \mathrm{EiC} 3) \mathrm{F} 1$ hybrid males. The parental generation was prepared in the research colony at the Jackson Laboratory and mating was performed at the Animal Facilities of the University of Cantabria. The euploid littermates of Ts65Dn mice served as controls. After weaning, the animals were separated by sex and were randomly assigned to and reared in either a standard nonenriched environment (NE) or an enriched environment. Mice were karyotyped after enrichment [56]. Since gender plays a significant role in the response to enrichment [8], our study used only females for Ts65Dn and control groups. Experimental procedures were performed following EU regulations and approved by the Ethics Committee for animal experimentation of the University of Cantabria.

\section{Housing and Enrichment Conditions}

The standard environment consisted of Plexiglas cages $(20 \times$ $12 \times 12 \mathrm{~cm}$ ); mice were housed 2 or 3 per cage under standard laboratory conditions $\left(20 \pm 2{ }^{\circ} \mathrm{C}, 12\right.$-hour light/12-hour dark cycle, 15:00 h light on, free access to food and water). For the EE experiments, we followed the protocol previously described [8]. In short, we used $42 \times 50 \times 20 \mathrm{~cm}$ cages with stainless steel ceiling, floor and frontal wall, and plastic lateral and back walls. Eight mice were housed per cage. The cage had two levels connected by a ladder and contained an activity wheel, a wooden swing and various plastic and wooden toys (toilet tissue rolls, blocks, rocks, etc. of different colors) which were changed every 3 days. Food of different tastes was added, with varying degrees of difficulty to get it. EE animals were maintained under the same light/dark cycle and controlled temperature as NE mice. After weaning, mice were reared for 7 weeks in an enriched environment and then returned to standard conditions. Cyclic adenosine monophosphate (cAMP) production was analyzed immediately after completing enrichment.

\section{Materials}

For the cAMP assay, 3-isobutyl-1-methyl-xantine, isoprenaline, cAMP, noradrenaline, forskolin and bovine serum albumin were supplied by Sigma Chemical Company (St. Louis, Mo., USA). Phenoxybenzamine was obtained from Smith Kline \& French Laboratories (Philadelphia, Pa., USA). $\left[{ }^{3} \mathrm{H}\right] \mathrm{CGP}-12177$ and $\left.{ }^{125} \mathrm{I}\right]$ cAMP radioimmunoassay kits were supplied by Amersham (Buckinghamshire, UK). For the inositol phosphate assays, atropine, carbachol, ketanserin, 5-methyltryptamine (5-MT), phosphatidylinositol 4,5-bisphosphate ( $\left.\mathrm{PIP}_{2}\right)$, and ATP were obtained from Sigma Chemical Company, guanosine 5'-O-(3-thiotriphosphate) (GTP $\gamma \mathrm{S})$ from Boehringer Mannheim (Spain), and $\left[{ }^{3} \mathrm{H}\right] \mathrm{PIP}_{2}$ (specific activity $6 \mathrm{Ci} / \mathrm{mmol}$ ) from New England Nuclear (USA). Liquid scintillation Optiphase Hi-Safe II was provided by LKB-FSA (Loughborough, UK).

\section{Preparation of Crude Plasma Membranes}

After decapitation, the 42- to 52-day-old mouse brains were removed and placed on ice. The cerebral cortex, the hippocampus, and the cerebellum were dissected free. The three brain regions were frozen on dry ice and stored at $-75^{\circ} \mathrm{C}$ until use. Frozen brain 
samples were thawed in ice-cold $20 \mathrm{~mm}$ Tris- $\mathrm{HCl}$ buffer, $\mathrm{pH}$ 7.0, containing 1 mM EGTA (Tris/EGTA buffer) prior to homogenization, then homogenized in 20 volumes of the same hypotonic buffer using a glass homogenizer with a Teflon pestle ( 20 strokes with a motor-driven pestle at maximum setting). A crude plasma membrane preparation was isolated by repeated centrifugations and rehomogenizations in the hypotonic buffer as described previously for human and rat cerebral cortex $[57,58]$. Briefly, the homogenate was centrifuged for $15 \mathrm{~min}$ at $40,000 \mathrm{~g}$. The pellet was then resuspended in Tris/EGTA buffer, rehomogenized, and centrifuged again. This procedure was repeated twice. Membranes were aliquots in microcentrifuge tubes and the pellets were kept at $-75^{\circ} \mathrm{C}$. There is no variation in PLC responsiveness to GTP $\gamma \mathrm{S}$ and agonists for at least 6 months of storage. Protein was measured using the Bio-Rad dye reagent.

\section{cAMP Assay}

The method of Slotkin et al. [59] was modified substituting GTP by GTP $\gamma \mathrm{S}$. The membrane preparations were diluted 20fold with $250 \mathrm{mM}$ sucrose, $1 \mathrm{~mm}$ ethylene glycolbis( $\beta$-aminoethylether)-N,N'-tetraacetic acid and $10 \mathrm{~mm}$ Tris (pH 7.4). Aliquots of membrane preparation containing $40 \mu \mathrm{g}$ of protein were then incubated for $10 \mathrm{~min}$ at $30^{\circ} \mathrm{C}$ with final concentrations of $100 \mathrm{mM}$ Tris-HCl (pH 7.4), $1 \mathrm{mM}$ adenosine $5^{\prime}$-triphosphate, $10 \mathrm{mM}$ $\mathrm{MgCl}_{2}, 1 \mathrm{mg}$ bovine serum albumin and a creatine-phosphokinase-ATP-generating system consisting of $10 \mathrm{~mm}$ sodium phosphocreatine, 8 IU of phosphocreatine kinase and $10 \mu \mathrm{M}$ GTP $\gamma \mathrm{S}$ in a total volume of $250 \mu$ l. The enzymatic reaction was stopped by placing the samples in a $90-100^{\circ} \mathrm{C}$ water bath for $5 \mathrm{~min}$, followed by sedimentation at $3,000 \mathrm{~g}$ for $15 \mathrm{~min}$. The supernatant solution was assayed for cAMP using $\left[{ }^{125} \mathrm{I}\right] \mathrm{cAMP}$ radioimmunoassay kits. Preliminary experiments showed that the enzymatic reaction was linear well beyond $10 \mathrm{~min}$ and with membrane protein concentration. Concentration of cofactors was optimal, and, in particular, addition of higher concentrations of GTP $\gamma S$ produced no further augmentation of activity. In addition to evaluating basal activity, the maximal total activity of the AC catalytic unit was evaluated with the response to forskolin $(100 \mu \mathrm{M})$ plus $\mathrm{Cl}_{2} \mathrm{Mn}(10 \mathrm{mM})$. $\mathrm{G}$ protein coupling to $\mathrm{AC}$ was determined using a nonhydrolyzable analog of GTP, the GTP $\gamma S(10 \mu \mathrm{M})$, and $\beta$-adrenergic stimulation of activity via $G$ s using isoprenaline $(100 \mu \mathrm{M})$ and noradrenaline $(100 \mu \mathrm{M})$, and $\mathrm{D}_{1}$-dopaminergic stimulation using SKF $38393(10 \mu \mathrm{M})$.

\section{PLC Assay}

The same membrane preparation used for AC activity assay was also used for basal and stimulated PLC assay. Membrane pellets were resuspended at a concentration of $2.5 \mathrm{mg}$ protein $/ \mathrm{ml}$ in a cold buffer consisting of $25 \mathrm{~mm}$ Tris-maleate, $5 \mathrm{mM}$ ATP, $15 \mathrm{mM}$ $\mathrm{MgCl}_{2}$, and $25 \mathrm{~mm} \mathrm{LiCl}, \mathrm{pH} 6.8$ (adjusted with $\mathrm{KOH}$ ). Reactions (100 $\mu$ l total volume) were initiated by adding $40 \mu$ l of membranes (100 $\mu$ g protein) to tubes with $25 \mathrm{mM}$ Tris-maleate, $\mathrm{pH}$ 6.8, containing $\left[{ }^{3} \mathrm{H}\right] \mathrm{PIP}_{2}$ (final concentration $30 \mu \mathrm{M}$ ), $1 \mathrm{mM}$ sodium deoxycholate, $3 \mathrm{~mm}$ EGTA and $\mathrm{CaCl}_{2}$ necessary to yield different free calcium concentrations (calculated according to Harafuji and Ogawa [60]). The function of PLC was assessed by measuring the hydrolysis of exogenous labeled phosphoinositides, e.g. $\left[{ }^{3} \mathrm{H}\right] \mathrm{PIP}_{2}$, and the production of $\left[{ }^{3} \mathrm{H}\right]$ inositol phosphates under basal conditions (50 nM calcium free) and after stimulation of neurotransmitter receptors and G protein coupling to PLC with a nonhydro- lyzable analog of GTP, GTP $\gamma S(10 \mu \mathrm{M})$, receptor-driven stimulation of PLC using the muscarinic agonist carbachol (1 mM), the $5-\mathrm{HT}_{2}$ agonist 5-methyltryptamine $(300 \mu \mathrm{M})$, and calcium $(10$ $\mu \mathrm{M})$.

The reactions were stopped with $1.2 \mathrm{ml}$ chloroform/methanol $(1: 2, \mathrm{v} / \mathrm{v})$, followed by $0.5 \mathrm{ml}$ of chloroform and $0.25 \mathrm{M} \mathrm{HCl}$ to create two phases, and were thoroughly vortexed. The phases were allowed to separate and then, after centrifugation, 1-ml aliquots of the upper aqueous phases containing $\left[{ }^{3} \mathrm{H}\right]$ inositol phosphates were mixed with $4 \mathrm{ml}$ of Optiphase Hi-Safe for scintillation counting.

\section{Data Analysis}

All experiments were carried out 4 times (4 biological samples), each in triplicate and with every experimental group being submitted to the experimental procedures (EE vs. NE) at the same time (each experiment containing a pool of 2 animals from each experimental group) $(n=4-6)$.

cAMP levels were calculated as picomoles of cAMP formed per milligram of protein, and the breakdown of $\left[{ }^{3} \mathrm{H}\right] \mathrm{PIP}_{2}$ by PLC was calculated as picomoles of $\mathrm{IP}_{3}$ formed per milligram of protein per minute. Data are expressed as means \pm SEM. Significance of the overall effect of the drugs was determined by twoway ANOVA followed by Duncan's multiple range tests and comparisons between groups were evaluated using Student's t test (two-tailed). The level of significance was set at $\mathrm{p}<0.05$. Statistical analysis was performed using SPSS for Windows v. 9.0.

\section{Results}

\section{Effects of EE on cAMP Production}

Basal production of cAMP after inhibition of phosphodiesterase activity by IBMX (1 mM) was similar in the hippocampus of Ts65Dn mice and wild-type littermates (fig. 1a). However, upon $\mathrm{G}$ protein stimulation by using GTP $\gamma$ S, even though cAMP accumulation was significantly increased compared to the basal state in both groups (euploid, $\mathrm{p}<0.001$, Ts65Dn, $\mathrm{p}<0.05$ ), significant differences among the groups were detected so that the values attained in the Ts65Dn group were significantly smaller compared to controls after stimulation with GTP $\gamma \mathrm{S}(\mathrm{t}=5.39, \mathrm{p}<0.0001$; fig. 1a). When the production of $c A M P$ was stimulated at the level of $\beta$-adrenergic and $\mathrm{D}_{1}$ receptors with isoprenaline $(10 \mu \mathrm{M})$, noradrenaline $(100 \mathrm{mM})$ and SKF $38393(10 \mu \mathrm{M})$, significant differences in the responses between groups were observed, though a significant increase compared to basal levels was induced in both groups of mice $(\mathrm{p}<0.05)$. The cAMP level attained was significantly lower in Ts65Dn than in control mice upon stimulation with isoprenaline $(t=8.65$, $\mathrm{p}<0.0001)$, noradrenaline $(\mathrm{t}=6.5, \mathrm{p}<0.0001)$ and forskolin $(t=3.62, \mathrm{p}<0.01)$. 

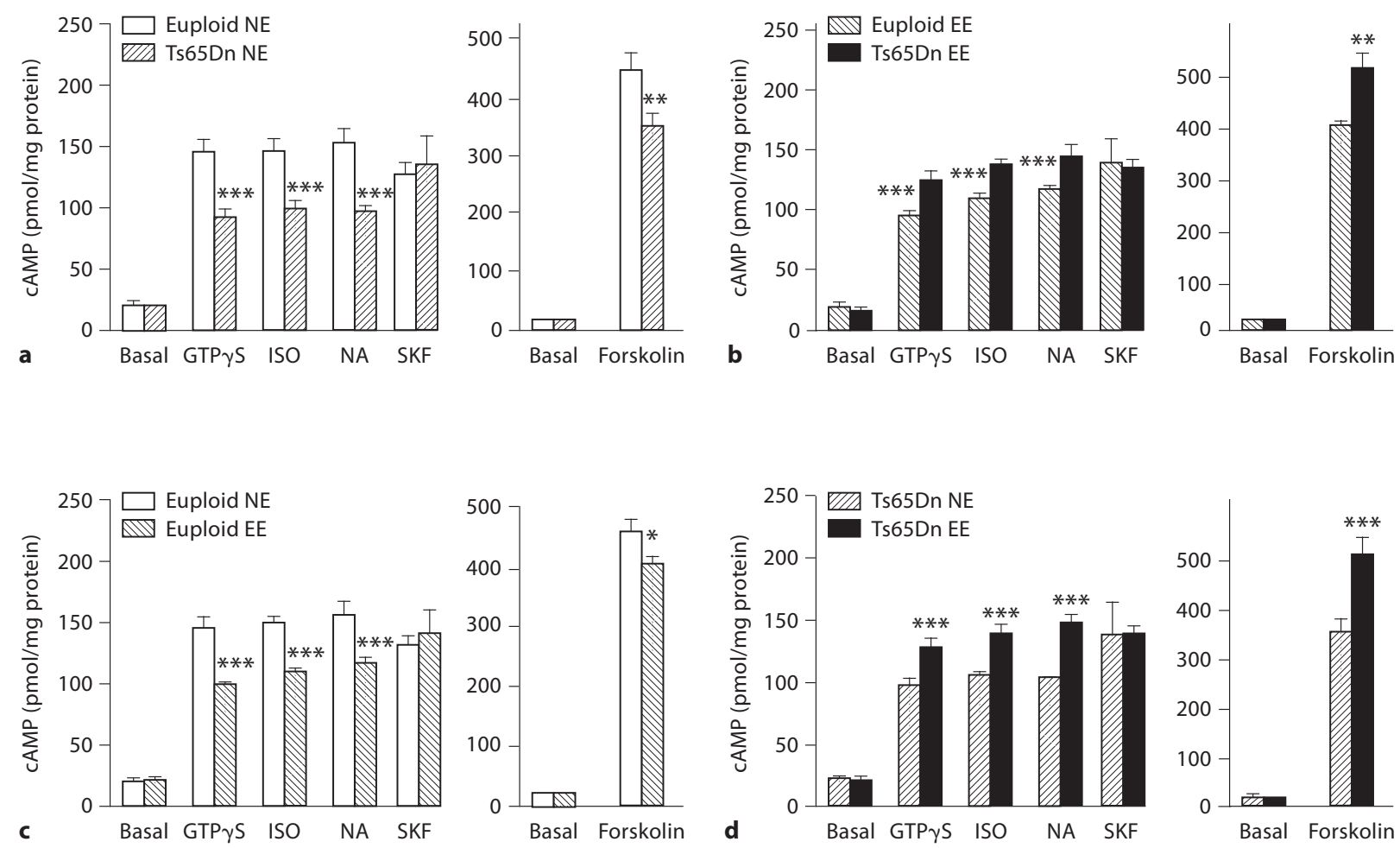

Fig. 1. Mean \pm SEM of basal cAMP accumulation and after stimulation with GTP $\gamma S$, isoprenaline (ISO), noradrenaline (NA), SKF 33893 and forskolin in the hippocampus of female nonenriched (NE) euploid versus Ts65Dn (a), enriched (EE) euploid versus Ts65Dn (b), euploid nonenriched versus enriched (c) and Ts65Dn nonenriched versus enriched (d) mice. ${ }^{*} \mathrm{p}<0.05 ;{ }^{* *} \mathrm{p}<0.01 ;{ }^{* * *} \mathrm{p}<0.001$ (Student's t test).

EE had differential effects in both genotypes. In female euploid mice, EE reduced cAMP activity (fig. 1c) after stimulation with GTP $\gamma \mathrm{S}(\mathrm{t}=5.4, \mathrm{p}<0.0001)$, isoprenaline $(\mathrm{t}=7.71, \mathrm{p}<0.0001)$, noradrenaline $(\mathrm{t}=4.34$, $\mathrm{p}<0.001)$ and forskolin $(\mathrm{t}=2.27, \mathrm{p}<0.05)$. However, in Ts65Dn females, EE significantly increased cAMP activity (fig. 1d) after stimulation with GTP $\gamma \mathrm{S}(\mathrm{t}=4.01$, $\mathrm{p}<$ $0.001)$, isoprenaline $(\mathrm{t}=4.81, \mathrm{p}<0.0001)$, noradrenaline $(\mathrm{t}=5.79, \mathrm{p}<0.0001)$ and forskolin $(\mathrm{t}=4.26, \mathrm{p}<0.001$ (fig. 1c). Ts65Dn enriched females showed an increase in cAMP accumulation with respect to enriched euploid females after stimulation with GTP $\gamma S(98.5 \pm 1.9$ vs. 125.4 \pm 6.4 in enriched control and Ts65Dn mice, respectively; $\mathrm{t}=4.0, \mathrm{p}<0.001$; fig. $1 \mathrm{~b})$, isoprenaline (111.2 $\pm 1.6 \mathrm{vs}$. $137.5 \pm 6.6$ in enriched control and Ts65Dn mice, respectively; $\mathrm{t}=3.8, \mathrm{p}<0.01)$, noradrenaline $(117.3 \pm 3.4$ vs. $145.2 \pm 7.4$ in enriched euploid and Ts65Dn mice, respectively; $\mathrm{t}=3.42, \mathrm{p}<0.01)$ and forskolin $(400.23 \pm$
9.4 vs. $507.1 \pm 31.4$ in enriched euploid and Ts65Dn mice, respectively; $\mathrm{t}=3.26, \mathrm{p}<0.01$ ).

\section{Effects of EE on PLC Activity}

In the hippocampus, Ts65Dn mice showed no differences in the accumulation of hydrolyzed PIP $_{2}$ in basal and GTP $\gamma$ S- or calcium-stimulated conditions. However, a reduction in PLC activity was observed after stimulation with 5-MT and carbachol, the latter reaching statistical significance $(t=2.7, p<0.01$; fig. $2 \mathrm{a})$. After EE, euploid mice showed a reduction in PLC activity after stimulation with carbachol $(t=2.72, p<0.01$; fig. $2 c)$, whereas Ts65Dn mice did not show changes in PLC activity under enriched conditions (fig. 2d). Thus, the differences observed upon carbachol stimulation between euploid and Ts65Dn mice in NE conditions disappeared after EE (fig. 2b). Contrary to euploid females, in trisomic mice EE produced a slight increase in PLC activity after stimulation 

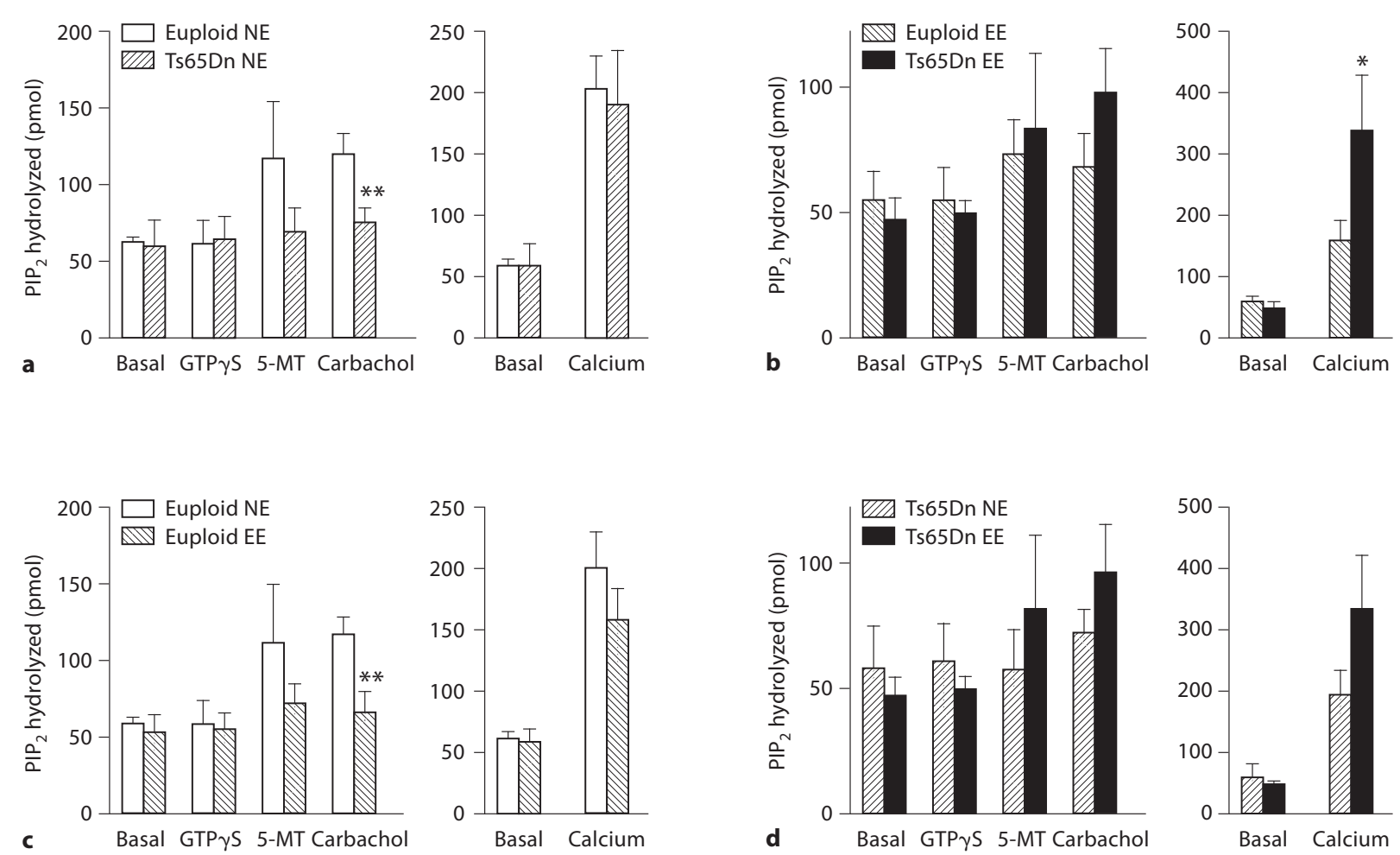

Fig. 2. Mean \pm SEM of basal PIP $P_{2}$ activity and after stimulation with GTP $\gamma S, 5-M T$, carbachol and calcium in the hippocampus of female nonenriched (NE) euploid versus Ts65Dn (a), enriched (EE) euploid versus Ts65Dn (b), euploid nonenriched versus enriched (c) and Ts65Dn nonenriched versus enriched (d) mice. ${ }^{*} \mathrm{p}<0.05$; ${ }^{* *} \mathrm{p}<0.01$ (Student's t test).

with 5-MT, carbachol and calcium, which, although not statistically significant, led to a significant difference in PLC activity after stimulation with calcium when compared to enriched euploid mice (159.07 \pm 26.22 vs. 340.5 $\pm 88.9 ; \mathrm{t}=1.96, \mathrm{p}<0.05$; fig. $2 \mathrm{~b})$.

\section{Discussion}

Special care programs are one of the most successful therapeutic interventions used in DS. However, their beneficial effects are limited in time. We aimed here at understanding how EE contributes to cellular mechanisms underlying learning and memory formation in DS. Our data show impairments in AC and PLC in Ts65Dn mice and suggest that EE has differential effects on these signaling systems depending on the genotype. Since our previous work demonstrated a lack of struc- tural plasticity upon enrichment in trisomic mice, these results may suggest that these transient biochemical effects are not translated into long-lasting structural changes.

Basal activity of AC was not affected in the hippocampus of trisomic mice, since cAMP accumulation was similar compared to wild-type littermates in both NE and EE conditions. However, when the system was challenged by receptor stimulation of $\beta$-adrenoceptor, or using GTP $\gamma S$, a nonhydrolyzable analog of GTP, or forskolin to directly activate the catalytic subunit of the enzyme, an impaired response was clearly detected in the trisomic mice. Our present results confirm the deficits we reported in the frontal and hippocampal cortices of young adult male Ts65Dn mice [29, 30], and in DS individuals [21], where we observed a severe deficiency in AC activity, with a very poor response to various stimulatory signals, including forskolin [21]. In the present work, this reduction was also 
detected in the hippocampus of Ts65Dn females that could be related to their learning deficits. In fact, longterm memory in a step-down active avoidance task was improved upon direct infusion of forskolin into the hippocampus [61].

Deregulation of the cAMP cascade is known to have an important role in neurogenesis [62] and synaptogenesis [63]. cAMP also regulates spine density by gating brain-derived neurotrophic factor signaling, a neurotrophin implicated in dendrite formation [64]. Several of these features are altered in DS. Furthermore, the reduced AC activity may lead to decreased activities of downstream PKA and some of its substrates, such as synapsin I, CREB or ARPP-19 (cAMP-regulated phosphoprotein) that are related to specific learning deficits associated with hippocampal function [53-55, 65].

However, no alterations in cAMP accumulation could be detected upon dopaminergic $\left(D_{1}\right)$ receptor stimulation with the $\mathrm{D}_{1}$ agonist SKF 38393 in either NE or EE rearing conditions in trisomic mice. This is in contrast to our previous data in human postmortem tissues [21], and may be seen as contradictory to previous reports showing reductions in dopamine and its acidic metabolites DOPAC and HVA, in DS fetal and adult brains [35, 40, 66]. Our study suggests that, even if dopamine levels are reduced, the $\mathrm{D}_{1}$-coupled postreceptor mechanisms may not be affected in the hippocampus of trisomic mice, contrary to the effects observed at the cortical or cerebellar levels [21,28].

When we analyzed the effects of EE in euploid mice, we could detect reduced cAMP production under basal conditions and after stimulation with a variety of signals: GTP $\gamma S, \beta$-adrenergic and dopaminergic agonists, and forskolin. This effect is comparable to those previously reported in rats, where environmental stimulation produced long-lasting reduction of central noradrenergic responsiveness [67], and postnatal handling induced shortand long-lasting depression of AC functioning [42, 43]. This may be explained since EE, when provided early in the life of normal animals, may also serve as a factor capable of moderating stressing responses, thus enabling the animals to cope more properly with learning challenges.

Interestingly, EE had opposite effects on TS mice, since it increased the production of cAMP upon G protein stimulation by using GTP $\gamma S$ and stimulation via Gs by the $\beta$-adrenergic agonists noradrenaline and isoprenaline, but again did not modify the response to the $\mathrm{D}_{1}$ dopaminergic agonist SKF 38393. In fact, contextual learning failure in Ts65Dn mice can be reversed by using a prodrug for norepinephrine called 1-threo-3,4-dihydroxyphenylserine, or xamoterol, a $\beta_{1}$-adrenergic receptor partial agonist [68]. We previously demonstrated beneficial effects of EE on cognition in female Ts65Dn mice $[6,8]$. However, the cognitive beneficial effects were not accompanied by structural plasticity changes in trisomic mice [7]. It is well documented that the AC system is a main determinant for neural structural plasticity [69-72] and derangement of this system has been argued to explain the cognitive and plasticity deficits in DS [72, 73]. However, it is not clear how these changes correlate to cognitive changes after environmental stimulation. In our study, EE downregulated the AC system in euploid mice and increased the activity of this system in TS female mice while improving cognition in mice of both genotypes. The cAMP system is known to be involved in mnemonic processing and anxiogenesis. However, both, increases and decreases in cAMP activity have been reported in different syndromes with altered cognition. cAMP is reduced in fragile $\mathrm{X}$ syndrome [74] but enhanced in autism [75, 76]. It has been proposed that in autism elevated cAMP may reflect a compensatory mechanism to increase low cAMP levels.

Furthermore, other molecular pathways have been shown to respond differently in Ts65Dn and euploid mice after pharmacological treatments. Siddiqui et al. [77] demonstrated that while in euploid mice the chr21-encoded proteins, TIAM1 and DYRK1A, and phosphorylation of AKT, ERK1/2 and the transcription factor ELK are involved in the locomotor stimulatory response of the NMDA receptor channel blocker MK-801, in Ts65Dn mice, levels of phosphorylation are constitutively elevated in naïve, unstimulated mice, and the MK-801-induced changes in TIAM1 and DYRK1A and in phosphorylation are either absent or abnormal, with both genotype- and brain region-specific patterns, emphasizing the complexities of the pathway perturbations that arise with segmental trisomy. Our data provide first direct evidence of restoration of the severe disturbances in the AC-signaling pathway using an environmental manipulation.

Regarding PLC functionality, basal and calcium- or GTP $\gamma$ S-stimulated $\mathrm{PIP}_{2}$ hydrolysis was preserved in the hippocampus of Ts65Dn mice under NE rearing conditions. However, we detected a reduction of PLC activity that reached statistical significance after muscarinic receptor stimulation, confirming our previous results in the cerebellum of male Ts65Dn mice [28]. This reduction points to a deficient cholinergic system at the hippocampal level that may explain some of the memory deficits present in Ts65Dn mice [78]. 
EE has been associated with increases in the functional efficiency of several neurotransmitter systems including the serotonergic and cholinergic systems and increases protein kinase $C$ levels [79-85]. Our data suggest that EE may compensate the ACh depletion in the hippocampus of Ts65Dn mice [78], by increasing the efficiency of their signal transduction system [86], but is also increasing calcium-stimulated $\mathrm{PIP}_{2}$ hydrolysis thus suggesting that the impact of EE could be broader increasing signaling through other neurotransmitter systems as well.

In conclusion, we here demonstrate that $\mathrm{EE}$ was able to increase G-protein-associated signal transduction processes in Ts65Dn mice. This effect might be partially dependent on a regulatory action on AC and PLC themselves since forskolin- and calcium-induced accumula- tion of cAMP and $\mathrm{PIP}_{2}$ were recovered. These changes, however, may not be effective in initiating structural plasticity that creates a stable trace over a long period of time [7].

\section{Acknowledgements}

The laboratory of M.D. is supported by DURSI (Grups consolidats 09 2009SGR1313). This work was supported by FCT08-0782, SAF2002-02178, SAF2007-60827, SAF2010-16427, SAF2007-31093-E, BFU2008-04397, FIS (PI 082038), Marató TV3, Jérôme Lejeune, Reina Sofía, Marcelino Botín and Areces Foundations and EU (LSHG-CT-2006-037627; CureFXS E-Rare: EU/FIS PS09102673). The CIBER of Enfermedades Raras is an initiative of the ISCIII. The funders had no role in the study design, data collection and analysis, decision to publish, or preparation of the manuscript.

\section{References}

1 Bricker D, Carlson L, Schwarz R: A discussion of early intervention for infants with down syndrome. Pediatrics 1981;67:45-46.

-2 Connolly BH, Morgan SB, Russell FF, Fulliton WL: A longitudinal study of children with Down syndrome who experienced early intervention programming. Phys Ther 1993; 73:170-179; discussion 179-181.

-3 Mahoney G, Perales F, Wiggers B, Herman B: Responsive teaching: early intervention for children with Down syndrome and other disabilities. Downs Syndr Res Pract 2006;11: $18-28$.

4 Dierssen M, Herault Y, Estivill X: Aneuploidy: from a physiological mechanism of variance to Down syndrome. Physiol Rev 2009; 89:887-920.

5 Lott IT, Dierssen M: Cognitive deficits and associated neurological complications in individuals with Down's syndrome. Lancet Neurol 2010;9:623-633.

-6 Martinez-Cue C, Rueda N, Garcia E, Davisson MT, Schmidt C, Florez J: Behavioral, cognitive and biochemical responses to different environmental conditions in male Ts65Dn mice, a model of Down syndrome. Behav Brain Res 2005;163:174-185.

7 Dierssen M, Benavides-Piccione R, Martinez-Cue C, Estivill X, Florez J, Elston GN, DeFelipe J: Alterations of neocortical pyramidal cell phenotype in the Ts65Dn mouse model of down syndrome: effects of environmental enrichment. Cereb Cortex 2003;13: 758-764.
8 Martinez-Cue C, Baamonde C, Lumbreras M, Paz J, Davisson MT, Schmidt C, Dierssen M, Florez J: Differential effects of environmental enrichment on behavior and learning of male and female Ts65Dn mice, a model for Down syndrome. Behav Brain Res 2002;134: 185-200.

-9 Dierssen M, Ortiz-Abalia J, Arque G, de Lagran MM, Fillat C: Pitfalls and hopes in Down syndrome therapeutic approaches: in the search for evidence-based treatments. Behav Genet 2006;36:454-468.

10 Davisson MT, Schmidt C, Reeves RH, Irving NG, Akeson EC, Harris BS, Bronson RT: Segmental trisomy as a mouse model for Down syndrome. Prog Clin Biol Res 1993; 384:117-133.

11 Reeves RH, Irving NG, Moran TH, Wohn A, Kitt C, Sisodia SS, Schmidt C, Bronson RT, Davisson MT: A mouse model for Down syndrome exhibits learning and behaviour deficits. Nat Genet 1995;11:177-184.

12 Hyde LA, Frisone DF, Crnic LS: Ts65Dn mice, a model for Down syndrome, have deficits in context discrimination learning suggesting impaired hippocampal function. Behav Brain Res 2001;118:53-60.

13 Wenger GR, Schmidt C, Davisson MT: Operant conditioning in the Ts65Dn mouse: learning. Behav Genet 2004;34:105-119.

14 Escorihuela RM, Fernandez-Teruel A, Vallina IF, Baamonde C, Lumbreras MA, Dierssen $\mathrm{M}$, Tobena A, Florez J: A behavioral assessment of Ts65Dn mice: a putative Down syndrome model. Neurosci Lett 1995;199: 143-146.
-15 Escorihuela RM, Vallina IF, Martinez-Cue C, Baamonde C, Dierssen M, Tobena A, Florez J, Fernandez-Teruel A: Impaired shortand long-term memory in Ts65Dn mice, a model for down syndrome. Neurosci Lett 1998;247:171-174.

16 Martinez-Cue C, Baamonde C, Lumbreras MA, Vallina IF, Dierssen M, Florez J: A murine model for down syndrome shows reduced responsiveness to pain. Neuroreport 1999;10:1119-1122.

-17 Stasko MR, Costa AC: Experimental parameters affecting the Morris water maze performance of a mouse model of Down syndrome. Behav Brain Res 2004;154:1-17.

18 Costa AC, Stasko MR, Schmidt C, Davisson MT: Behavioral validation of the Ts65Dn mouse model for down syndrome of a genetic background free of the retinal degeneration mutation Pde6b(rd1). Behav Brain Res 2010;206:52-62.

19 Fernhall B, Otterstetter M: Attenuated responses to sympathoexcitation in individuals with Down syndrome. J Appl Physiol 2003;94:2158-2165.

20 Mafrica F, Fodale V: Opioids and Down's syndrome. J Opioid Manag 2006;2:93-98.

-21 Lumbreras M, Baamonde C, Martinez-Cue C, Lubec G, Cairns N, Salles J, Dierssen M, Florez J: Brain G protein-dependent signaling pathways in Down syndrome and Alzheimer's disease. Amino Acids 2006;31:449456. 
-22 Garofolo MC, Seidler FJ, Auman JT, Slotkin TA: Beta-adrenergic modulation of muscarinic cholinergic receptor expression and function in developing heart. Am J Physiol Regul Integr Comp Physiol 2002;282:R1356R1363.

23 Huang W, Galdzicki Z, van Gelderen P, Balbo A, Chikhale EG, Schapiro MB, Rapoport SI: Brain myo-inositol level is elevated in Ts$65 \mathrm{Dn}$ mouse and reduced after lithium treatment. Neuroreport 2000;11:445-448.

24 Shetty HU, Siarey RJ, Galdzicki Z, Stoll J, Rapoport SI: Ts65Dn mouse, a Down syndrome model, exhibits elevated myo-inositol in selected brain regions and peripheral tissues. Neurochem Res 2000;25:431-435.

25 Brooksbank BW, Martinez M: Lipid abnormalities in the brain in adult Down's syndrome and Alzheimer's disease. Mol Chem Neuropathol 1989;11:157-185.

-26 Murphy EJ, Schapiro MB, Rapoport SI, Shetty HU: Phospholipid composition and levels are altered in down syndrome brain. Brain Res 2000;867:9-18.

-27 Shetty HU, Schapiro MB, Holloway HW, Rapoport SI: Polyol profiles in Down syndrome. Myo-inositol, specifically, is elevated in the cerebrospinal fluid. J Clin Invest 1995; 95:542-546.

28 Ruiz de Azua I, Lumbreras MA, Zalduegui A, Baamonde C, Dierssen M, Florez J, Salles $\mathrm{J}$ : Reduced phospholipase C-beta activity and isoform expression in the cerebellum of TS65Dn mouse: a model of Down syndrome. J Neurosci Res 2001;66:540-550.

29 Dierssen M, Vallina IF, Baamonde C, Lumbreras MA, Martinez-Cue C, Calatayud SG, Florez J: Impaired cyclic AMP production in the hippocampus of a Down syndrome murine model. Brain Res Dev Brain Res 1996;95: 122-124.

- 30 Dierssen M, Vallina IF, Baamonde C, Garcia-Calatayud S, Lumbreras MA, Florez J: Alterations of central noradrenergic transmission in Ts65Dn mouse, a model for Down syndrome. Brain Res 1997;749:238244.

-31 Bar-Peled O, Israeli M, Ben-Hur H, Hoskins I, Groner Y, Biegon A: Developmental pattern of muscarinic receptors in normal and Down's syndrome fetal brain - an autoradiographic study. Neurosci Lett 1991;133:154158.

- 32 Fiedler JL, Epstein CJ, Rapoport SI, Caviedes $\mathrm{R}$, Caviedes P: Regional alteration of cholinergic function in central neurons of trisomy 16 mouse fetuses, an animal model of human trisomy 21 (Down syndrome). Brain Res 1994;658:27-32.

33 Granholm AC, Sanders LA, Crnic LS: Loss of cholinergic phenotype in basal forebrain coincides with cognitive decline in a mouse model of Down's syndrome. Exp Neurol 2000;161:647-663.
4 Kleschevnikov AM, Belichenko PV, Villar AJ, Epstein CJ, Malenka RC, Mobley WC: Hippocampal long-term potentiation suppressed by increased inhibition in the Ts65Dn mouse, a genetic model of Down syndrome. J Neurosci 2004;24:8153-8160.

35 Whittle N, Sartori SB, Dierssen M, Lubec G, Singewald N: Fetal Down syndrome brains exhibit aberrant levels of neurotransmitters critical for normal brain development. Pediatrics 2007;120:e1465-e1471.

36 Sun Y, Dierssen M, Toran N, Pollak DD, Chen WQ, Lubec G: A gel-based proteomic method reveals several protein pathway abnormalities in fetal Down syndrome brain. J Proteomics 2011;74:547-557.

37 Belichenko PV, Kleschevnikov AM, Masliah E, Wu C, Takimoto-Kimura R, Salehi A, Mobley WC: Excitatory-inhibitory relationship in the fascia dentata in the Ts65Dn mouse model of Down syndrome. J Comp Neurol 2009;512:453-466.

38 Cooper-Kuhn CM, Winkler J, Kuhn HG: Decreased neurogenesis after cholinergic forebrain lesion in the adult rat. J Neurosci Res 2004;77:155-165.

39 Bar-Peled O, Gross-Isseroff R, Ben-Hur H, Hoskins I, Groner Y, Biegon A: Fetal human brain exhibits a prenatal peak in the density of serotonin 5-HT1A receptors. Neurosci Lett 1991;127:173-176.

40 Risser D, Lubec G, Cairns N, HerreraMarschitz M: Excitatory amino acids and monoamines in parahippocampal gyrus and frontal cortical pole of adults with Down syndrome. Life Sci 1997;60:1231-1237.

41 Bianchi P, Ciani E, Guidi S, Trazzi S, Felice D, Grossi G, Fernandez M, Giuliani A, Calza L, Bartesaghi R: Early pharmacotherapy restores neurogenesis and cognitive performance in the Ts65Dn mouse model for down syndrome. J Neurosci;30:8769-8779.

42 Baamonde C, Lumbreras MA, MartinezCue C, Vallina IF, Florez J, Dierssen M: Postnatal handling induces long-term modifications in central beta-noradrenergic signalling in rats. Stress 2002;5:137-147.

43 Baamonde C, Lumbreras MA, MartinezCue C, Vallina IF, Garcia-Calatayud S, Florez J, Dierssen M: Short-term effects of postnatal manipulation on central beta-adrenoceptor transmission. Stress 1999;3:147-162.

-44 Moran TH, Capone GT, Knipp S, Davisson MT, Reeves RH, Gearhart JD: The effects of piracetam on cognitive performance in a mouse model of Down's syndrome. Physiol Behav 2002;77:403-409.

45 Insausti AM, Megias M, Crespo D, CruzOrive LM, Dierssen M, Vallina IF, Insausti R, Florez J: Hippocampal volume and neuronal number in Ts65Dn mice: a murine model of Down syndrome. Neurosci Lett 1998;253: 175-178.
6 Kurt MA, Kafa MI, Dierssen M, Davies DC: Deficits of neuronal density in CA1 and synaptic density in the dentate gyrus, CA3 and CA1, in a mouse model of Down syndrome. Brain Res 2004;1022:101-109.

-47 Kurt MA, Davies DC, Kidd M, Dierssen M, Florez J: Synaptic deficit in the temporal cortex of partial trisomy 16 (Ts65Dn) mice. Brain Res 2000;858:191-197.

48 Lorenzi HA, Reeves RH: Hippocampal hypocellularity in the Ts65Dn mouse originates early in development. Brain Res 2006; 1104:153-159.

49 Costa AC, Grybko MJ: Deficits in hippocampal CA1 LTP induced by TBS but not HFS in the Ts65Dn mouse: a model of Down syndrome. Neurosci Lett 2005;382:317-322.

50 Galdzicki Z, Siarey R, Pearce R, Stoll J, Rapoport SI: On the cause of mental retardation in down syndrome: extrapolation from full and segmental trisomy 16 mouse models. Brain Res Brain Res Rev 2001;35:115-145.

-51 Best TK, Cho-Clark M, Siarey RJ, Galdzicki Z: Speeding of miniature excitatory postsynaptic currents in Ts65Dn cultured hippocampal neurons. Neurosci Lett 2008;438: 356-361.

52 Siarey RJ, Stoll J, Rapoport SI, Galdzicki Z: Altered long-term potentiation in the young and old Ts65Dn mouse, a model for Down syndrome. Neuropharmacology 1997;36: 1549-1554.

53 Siarey RJ, Kline-Burgess A, Cho M, Balbo A, Best TK, Harashima C, Klann E, Galdzicki Z: Altered signaling pathways underlying abnormal hippocampal synaptic plasticity in the Ts65Dn mouse model of Down syndrome. J Neurochem 2006;98:1266-1277.

54 Pennington BF, Moon J, Edgin J, Stedron J, Nadel L: The neuropsychology of Down syndrome: evidence for hippocampal dysfunction. Child Dev 2003;74:75-93.

55 Pinter JD, Brown WE, Eliez S, Schmitt JE, Capone GT, Reiss AL: Amygdala and hippocampal volumes in children with Down syndrome: a high-resolution MRI study. Neurology 2001;56:972-974.

56 Davisson MT, Akeson EC: An improved method for preparing G-banded chromosomes from mouse peripheral blood. Cytogenet Cell Genet 1987;45:70-74.

57 Wallace MA, Claro E: Transmembrane signaling through phospholipase $\mathrm{C}$ in human cortical membranes. Neurochem Res 1993; 18:139-145.

58 Salles J, Wallace MA, Fain JN: Modulation of the phospholipase $\mathrm{C}$ activity in rat brain cortical membranes by simultaneous activation of distinct monoaminergic and cholinergic muscarinic receptors. Brain Res Mol Brain Res 1993;20:111-117.

59 Slotkin TA, Zhang J, McCook EC, Seidler FJ: Glucocorticoid-targeting of the adenylyl cyclase signaling pathway in the cerebellum of young vs. aged rats. Brain Res 1998;800:236244. 
-60 Harafuji H, Ogawa Y: Re-examination of the apparent binding constant of ethylene glycol bis(beta-aminoethyl ether)-N,N, $\mathrm{N}^{\prime}, \mathrm{N}^{\prime}$ tetraacetic acid with calcium around neutral pH. J Biochem 1980;87:1305-1312.

-61 Bernabeu R, Bevilaqua L, Ardenghi P, Bromberg E, Schmitz P, Bianchin M, Izquierdo I, Medina JH: Involvement of hippocampal cAMP/cAMP-dependent protein kinase signaling pathways in a late memory consolidation phase of aversively motivated learning in rats. Proc Natl Acad Sci USA 1997;94: 7041-7046.

-62 Nakagawa S, Kim JE, Lee R, Malberg JE, Chen J, Steffen C, Zhang YJ, Nestler EJ, Duman RS: Regulation of neurogenesis in adult mouse hippocampus by cAMP and the cAMP response element-binding protein. J Neurosci 2002;22:3673-3682.

-63 Otte AP, van Run P, Heideveld M, van Driel $\mathrm{R}$, Durston AJ: Neural induction is mediated by cross-talk between the protein kinase $\mathrm{C}$ and cyclic AMP pathways. Cell 1989;58:641648.

64 Ji Y, Pang PT, Feng L, Lu B: Cyclic AMP controls BDNF-induced TrkB phosphorylation and dendritic spine formation in mature hippocampal neurons. Nat Neurosci 2005;8: 164-172.

65 Beacher F, Simmons A, Daly E, Prasher V, Adams C, Margallo-Lana ML, Morris R, Lovestone S, Murphy K, Murphy DG: Hippocampal myo-inositol and cognitive ability in adults with Down syndrome: an in vivo proton magnetic resonance spectroscopy study. Arch Gen Psychiatry 2005;62:13601365.

66 Schneider C, Risser D, Kirchner L, Kitzmuller E, Cairns N, Prast H, Singewald N, Lubec G: Similar deficits of central histaminergic system in patients with Down syndrome and Alzheimer disease. Neurosci Lett 1997;222: 183-186.

67 Escorihuela RM, Fernandez-Teruel A, Tobena A, Vivas NM, Marmol F, Badia A, Dierssen M: Early environmental stimulation produces long-lasting changes on beta-adrenoceptor transduction system. Neurobiol Learn Mem 1995;64:49-57.
68 Salehi A, Faizi M, Colas D, Valletta J, Laguna J, Takimoto-Kimura R, Kleschevnikov A, Wagner SL, Aisen P, Shamloo M, Mobley WC: Restoration of norepinephrine-modulated contextual memory in a mouse model of Down syndrome. Sci Transl Med 2009;1: 7 ra17.

69 Zhong Y, Wu CF: Neuronal activity and adenylyl cyclase in environment-dependent plasticity of axonal outgrowth in drosophila. J Neurosci 2004;24:1439-1445.

70 Barth AL, McKenna M, Glazewski S, Hill P, Impey S, Storm D, Fox K: Upregulation of cAMP response element-mediated gene expression during experience-dependent plasticity in adult neocortex. J Neurosci 2000;20 4206-4216.

71 Nguyen PV, Woo NH: Regulation of hippocampal synaptic plasticity by cyclic AMPdependent protein kinases. Prog Neurobiol 2003;71:401-437.

72 Jancic D, Lopez de Armentia M, Valor LM, Olivares R, Barco A: Inhibition of cAMP response element-binding protein reduces neuronal excitability and plasticity, and triggers neurodegeneration. Cereb Cortex 2009; 19:2535-2547.

73 Pittenger C, Fasano S, Mazzocchi-Jones D, Dunnett SB, Kandel ER, Brambilla R: Impaired bidirectional synaptic plasticity and procedural memory formation in striatumspecific cAMP response element-binding protein-deficient mice. J Neurosci 2006;26: 2808-2813.

74 Kelley DJ, Davidson RJ, Elliott JL, Lahvis GP, Yin JC, Bhattacharyya A: The cyclic AMP cascade is altered in the fragile $\mathrm{X}$ nervous system. PLoS One 2007;2:e931.

75 Hoshino Y, Kumashiro H, Yashima Y, Kaneko M, Numata Y, Oshima N, Watanabe A: Plasma cyclic AMP level in psychiatric diseases of childhood. Folia Psychiatr Neurol Jpn 1980;34:9-16.

76 Cook EH: Autism: review of neurochemical investigation. Synapse 1990;6:292-308.

77 Siddiqui A, Lacroix T, Stasko MR, ScottMcKean JJ, Costa AC, Gardiner KJ: Molecular responses of the Ts65Dn and Ts1Cje mouse models of Down syndrome to MK801. Genes Brain Behav 2008;7:810-820.
8 Cooper JD, Salehi A, Delcroix JD, Howe CL, Belichenko PV, Chua-Couzens J, Kilbridge JF, Carlson EJ, Epstein CJ, Mobley WC: Failed retrograde transport of NGF in a mouse model of Down's syndrome: reversal of cholinergic neurodegenerative phenotypes following NGF infusion. Proc Natl Acad Sci USA 2001;98:10439-10444.

79 McOmish CE, Burrows E, Howard M, Scarr E, Kim D, Shin HS, Dean B, van den Buuse M, Hannan AJ: Phospholipase C-betal knockout mice exhibit endophenotypes modeling schizophrenia which are rescued by environmental enrichment and clozapine administration. Mol Psychiatry 2008;13:661-672.

80 Massicotte G: Modification of glutamate receptors by phospholipase A2: its role in adaptive neural plasticity. Cell Mol Life Sci 2000; 57:1542-1550.

81 De Bartolo P, Leggio MG, Mandolesi L, Foti F, Gelfo F, Ferlazzo F, Petrosini L: Environmental enrichment mitigates the effects of basal forebrain lesions on cognitive flexibility. Neuroscience 2008; 154:444-453.

82 Tees RC: The influences of rearing environment and neonatal choline dietary supplementation on spatial learning and memory in adult rats. Behav Brain Res 1999;105:173-188.

83 Paban V, Chambon C, Manrique C, Touzet C, Alescio-Lautier B: Neurotrophic signaling molecules associated with cholinergic damage in young and aged rats environmental enrichment as potential therapeutic agent. Neurobiol Aging 2011;32:470-485.

84 Eaton MJ, Pearse DD, McBroom JS, Berrocal YA: The combination of human neuronal serotonergic cell implants and environmental enrichment after contusive SCI improves motor recovery over each individual strategy. Behav Brain Res 2008;194:236-241.

85 Ueda S, Sakakibara S, Yoshimoto K: Effect of long-lasting serotonin depletion on environmental enrichment-induced neurogenesis in adult rat hippocampus and spatial learning. Neuroscience 2005;135:395-402.

86 Frechette M, Rennie K, Pappas BA: Developmental forebrain cholinergic lesion and environmental enrichment: behaviour, CA1 cytoarchitecture and neurogenesis. Brain Res 2009;1252:172-182. 